\title{
Employee Empowerment and Job Performance: The Case of a Few Selected BPOs/KPOs in the City of Pune
}

\author{
Sweta Banerjee
}

\begin{abstract}
Job performance/JP/ is the direct and indirect contribution of an individual towards the organizational goals and objectives and can be achieved by employee empowerment. The main purpose of this study was to explore the effect of employee empowerment on their job performance. The research has been designed as a descriptive study. Both primary and secondary data were used in the research. A survey questionnaire with five point Likert scale was a main tool for gathering primary data about employee empowerment effect on job performance. A total of 373 (15\% of the population) participants in the various offices of the BPOs and KPOs who participated in filling the questionnaires. These participants were selected using both simple random and purposive sampling method. The results of the data analysis show that there is employee empowerment in the organizations, because $90 \%$ of the respondents replied that they agreed to the existence of employee empowerment in this industry. As a result, there is an improvement of performance in the jobs in the organization. However, the ability to perform jobs and goal achievement are generally not enough. There is interference of supervisors in the process and hence the result shows that $71 \%$ of the management and $70 \%$ employees of respondents agreed on it. This indicates that, autonomy is not properly practiced in the organization. Moreover, information sharing among the three employee empowerment variables used in the study is not practiced, because around $75 \%$ of management and $83 \%$ of employee respondents disagreed to regarding 'creation of understanding of the reasons for decision in the organization.' The major challenges are lack of promotion, lack of training and lack of clear job description in regard to employee empowerment which are the major findings in the study Finally, the researcher has forwarded suggestions and recommendations for different groups pertaining to employee empowerment (regarding to autonomy by reducing interference, information sharing by creating understanding about the reason of decision making and also self-managing team by minimizing supervisor role) and alleviate challenges (like lack of rank promotion, lack of long term goals and lack of clear job description).
\end{abstract}

\section{INTRODUCTION}

We are in a process through which it is well understood that 'human' asset is one of the most reliable sources of organizational performance, efficiency and effectiveness, and organizations are expecting from their employees to demonstrate higher levels of efficiency, effectiveness, and

Revised Manuscript Received on July 22, 2019.

Dr. Sweta Banerjee, Professor, Balaji Institute of Telecom and Management, Sri Balaji University, Pune performance. Work processes which are getting more complex and gradually challenging conditions of competition are the other factors which heighten the expectations of organizations from their human resources. This requires human resources to have various additional competences. Aforesaid requirement brings about the need to consider human resources management through a new approach, away from the traditional understanding. According to Pattanayak, (2009) suggest that in the dynamic business world, competition is inevitable. Yesterday's best organizations are disappearing from today's list of the best.

After the Liberalization, Privatization and Globalization (LPG) process in the early 1990s, organizations realized the fact that the people are the centre of the whole system. For creating a performing organization and to sustain the performance, human resource orientation needs to be top-down and should also involve the line managers to ensure sustainable high performance (Pattanayak, 2009). When human being 'manage' their work, they take responsibility for its purpose, progress and outcome by exercising the typically human capacity to stand back from experience and to regard it prospectively, in term of what will happen; reflectively, in terms of what is happening; and retrospectively, in terms of what has happen (Boddy, 2011). People are the means by which organizations get things done. Empowerment essentially is the granting of authority to employees to make key decisions with their enlarged areas of responsibility. The driving idea of empowerment is that individual close to the work and to customers should make the decision (Mosley, pietri and Mosley, 2008).

As Redman and Wildison, (2001) said that: Empowerment is generally used to refer to a form of initiative which was widespread from the 1980s and focused on task based involvement and attitudinal change. It is a win-win scenario with gains available both to employer (increase efficiency) and workers (performance). 'Employee empowerment represents the most recent manifestation of involvement practice' (Cunningham et al., 1996 cited in Redman and Wildison, 2001).

For employees, empowerment provides a sense of high self-esteem, high degree of involvement and participation, a learning environment opportunity for personal growth and development and a greater sense of achievement. Replacing the 'fear and greed' hierarchy with network of empowered workers creates benefits like 
faster responses, loyal customers, high quality-lower costs, greater productivity and employee orientation (carter, 2000 cited in Bisaeet Pattanayak (2009).

The aim of empowerment, therefore, is not primarily democratic. They are, instead, economic and are focused upon the attempt to improve economic and performance in terms of both productivity and quality organization (Tom Redman and Adrian wilkinson, 2001). Human resource is the most valuable asset of an organization. Empowerment gives the employees a degree of responsibility and authority. Empowerment encourages the employees to utilize their skills, abilities and creativity by accepting accountability for their work. The most related outcomes of employee empowerment are performance and job performance (JP). Empowerment was expected to have both direct and indirect effects on satisfaction (Indradevi, 2012).

Pattanayak, (2009) suggests that empowerment benefit the organization itself by creating an environment which encourages proactively problem-solving, accepting challenge, innovation, continuous improvement, and optimum utilization of employees, a high degree of employee motivation and enhancement of business performance.

In India, the concept and practice of empowerment begun at the begging of 1991, with BPR, because the existence of BPR promote practice of employee empowerment. Due to service delivery dissatisfaction and growing consciences amongst the community which became the root cause of the all-round crisis in the country. India began to promote efficiency (by minimizing cost and time of processes) and effectiveness to deliver customer friendly service and customer oriented organization. It is believed that this became the foundation for improving the performance of employees. And it is the base for good economic development of the country.

Different organizations use their own variables to understand and explain employee empowerment. The followings are a series of basic variables that reflect the organization behavior of what should and could constitute employee empowerment in the BPO/KPO sector. In this research, the researcher focused on the main variables, like autonomy, communication and self-directed work teams.

Therefore, this research paper has been taken as an attempt to examine the practice of employee empowerment in this sector. The objective of the study is to investigate the effects of perceived employee empowerment (autonomy, communication and self-managing work teams) on performance of employees in regard to the organization and its effectiveness in improving the performances of employees. Moreover, the study also focused on the effect of employee empowerment on worker performance in the organizations. The study intends to inform the management of the organizations, that in order to increase performance, there is a need to have well empowered and motivated employees.

\section{Statement of the problem}

Nowadays environment changes rapidly and exhibits a challenging situation to organizations and companies. In order to be successful and stay competitive in the future they have therefore to look beyond the traditional directive management (Wörlein, 2010).

People manage all the resources of the organization for effective and efficient utilization. Therefore, human resources are the most valuable assets of organizations. Each and every resource has value but the value of the resources is different to one another.

Now day's employees' in an organization are more qualified and well experienced in there jobs than ever before. The number of qualified employees' in various professions is increasing. Empowered employees have complete knowledge about their work, so that they plan and schedule their work and are capable of identifying and resolving any obstacles for their performance (Indradevi, 2012).

Therefore, these people are more capable of to perform tasks that are assigned to them effectively and efficiently. The empowerment of employees allows them more control and responsibility over their work. While the role of managers' shifts from control to facilitation and coordination of work processes (Jordanian, 2004). So, employees need not wait for orders from their superiors to perform a task/job. As a result, today, the issue of empowerment is a concern in workplace which might affect the employees' job performance. If employees' are not empowered in their jobs, autonomy is not given and information sharing and self-managing team are not encouraged, the resultant effect may deteriorate employees' moral, productivity and employees' job performance might, and a lot of working hours may be wasted awaiting supervisors direction to complete a task.

Objective of the study

The main purpose of this study is to investigate the impact of empowerment on employee's performance in some selected BPOs/KPOs in the city of Pune.

\section{CONCEPT OF EMPLOYEE EMPOWERMENT (EE)}

Nowadays, environment is changing rapidly and exhibits a challenging situation to organizations and companies. In order to be successful and stay competitive in the future they have to therefore look beyond the traditional directive management. The contribution of more than a single individual (manager) is necessary, and employees are not only expected but also needed to assume an active rather than a passive role in the organization.

The success of the organization is now in the hands of employees who are ready to deliver it. So in recent years empowerment has become fashionable in different organization, according to (Koontz and Weihrich, 2005) empowerment means that employees, managers, or teams at all levels in the organization have the power to make decisions without asking their superiors for permission. As noted, Empowerment is a shared understanding between managers and employees that employees are trusted and valued partners. Because they are in the best position to assume responsibility for individual and team results, employees take action and make decisions that support the organization's goals. Managers acting as coaches align goals, measures, and resources in a

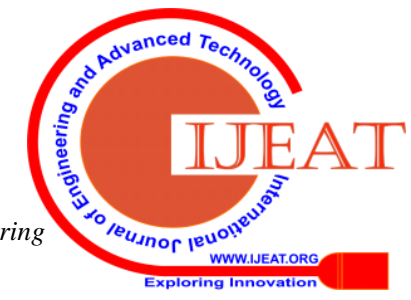


climate of trust and open feedback (Carroll, 1994).

Some of the reasons for the interest in empowerment are the global competitiveness, the need to respond fast to the demands and expectations of customers, and the better educated work force which demands greater autonomy. Empowerment of subordinates means that superiors have to share their authority and power with their subordinate.

Thus, an autocratic leadership style, when used as the only way to manage, is often inappropriate for the twenty first century organization. Most of the employees would like to be involved and want to participate in decisions, which, in turn, creates a sense of belonging, achievement, and self-esteem (Koontz and Weihrich , 2005).Empowerment is to leverage our resources in a competitive environment where speed, efficiency, innovation, and commitment to service are required (Carroll, 1994). Effective management requires that the empowerment: (1) is sincere, (2) is based on mutual trust, (3) provides the employees with relevant information to carry out their tasks, and (4) is given to competent people. One must also realize the impact of subordinate empowerment on their superiors. The needs of superiors must be recognized by, for example, giving them tasks that are more challenging (Koontz and Weihrich, 2005). The empowerment of human resources is usually used in the same meaning with authorizing and assigning responsibility, in other words, as empowering and transfer of authority. It should be noted that this understanding has some deficiencies. It is a need for human resources to empower. However, empowerment has to have some more aspects such as motivation and taking part in. Employee empowerment starts from high level managers; and continues with the understanding of vision, mission and values of the organization and the applications which enables the employees to feel themselves responsible, free, and competent for the organization. Employee empowerment is also a period which consists of taking risks, development and change (Theron, 2010). Finally, the researcher concluded that employee empowerment indicates all these things. Therefore, employee empowerment in the organizational context is related to the person who is working in the organization, sharing the authority and power with their subordinate and accomplish their job description

\section{1) Advantages of employee empowerment in the organization}

The main purpose of the employee empowerment is to strengthen the achievement motives of the employees and therefore increase their "contextual performance" with the devices such as fertility, efficiency, work satisfaction, and organizational dependence (Theron, 2010). Further advantages initiated by a successful implementation of empowerment in the organization: Increased productivity, Greater employee enthusiasm, Increased morale and creativity, Higher quality products and services, Improved teamwork, Increased speed and responsiveness, Lessened emotional impact of demoralizing organizational changes and restructuring, After looking on these miscellaneous advantages, the implementation of the empowerment seems very reasonable to companies and employees likewise (Wörlein, 2010).

According to Peters and Mazdarani (2008), they stated implications of employee empowerment in service organizations. Many service management literature suggests its benefits as related to both customer and employee satisfaction. As listed by Grönroos (2001) cited in Peters and Mazdarani that the benefits are:

$>$ Quicker and more direct response to customer needs: customers experience spontaneity and willingness to help by the employees at unusual circumstances compared to the traditional mode of having to wait for a decision by a supervisor. This has an effect on perceived service quality.

$>$ Quicker and more direct response to dis-satisfied customers in service recovery: like as above employees are able to help them recover in event of service failure without the supervisor's intervention.

$>$ Employees are more satisfied with their jobs and feel better about themselves: the feeling of job ownership leads to less job absenteeism and reduced employee turnover.

$>$ Employees will treat customers more enthusiastically: considering the motivating effect of empowerment, they become enthusiastic part-time marketers.

$>$ Empowered employees can be a valuable source of new ideas: as a result of direct customer contacts they have insights into customer problems, ideas and wishes which they can share with management to facilitate improvements.

$>$ Empowered employees are instrumental to creating good word of mouth referrals and increasing customer retention: as a result of serving customers in a quick, skillful and service-oriented manner, surprising them and making them spread good word of mouth and stay with the same service provider.

Generally, from the researcher's point of view we can conclude that it has the purpose by increase the achievement motives of the employees and increase their job performance with the devices such as efficiency, work satisfaction, and increased productivity. As we have seen these advantages, the implementation of the empowerment seems very reasonable to companies and their employees likewise.

The dimensions of employee empowerment

Various service literature (Looy, 2003) and (Zeithaml, 2006), cited in (Silvia C. Peters and Elham Mazdarani, 2008), describe employee empowerment as having many dimensions ranging from the individual employee level to the organization level of empowerment.

And also (Looy, 2003) cited in (Silvia C. Peters and Elham Mazdarani, 2008), points out that the most important reason for empowerment at the

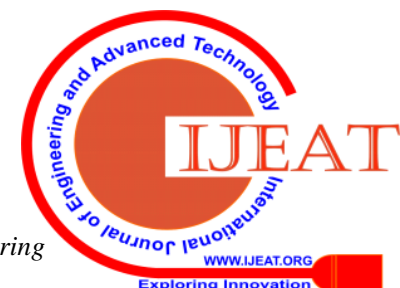


individual employee level is the belief that autonomy motivates people, they further argue that people are willing to take initiatives and make decisions rather than being dictated to regarding their jobs. With reference to Looy, (2003), there are five dimensions as a driving force behind individual work motivation:

\section{The individual employee level:}

Meaning: the extent to which an individual experiences a task as personally meaningful.

Competence: the extent to which an individual feels confident about his/her capabilities to perform the task.

Self-determination: the degree of influence that an individual has on how to perform the job.

Strategic autonomy: the degree of influence an individual has on the content of the job.

Impact: the degree of influence an individual has on the direct work environment.

The organization level:

Looy et al (2003:237), points out that employees cannot be empowered without the necessary organizational support that are required to stimulate actions such as taking initiatives and acting independently. For employees to be successfully empowered, the organization needs to create the environment where such attitudes and behaviors can be developed.

According to Looy et al (2003:238), "empowered organizations have everything in place to facilitate the pushing down of information, knowledge, rewards, and power".

Sharing information (SI): empowerment of employees would be unsuccessful if they have no access to information about the (a) service concept (b) the service delivery process a hole(c) past and current performance of the organization as a whole and (d) setting of goals in the organization by knowing what needs to be done, not what is allowed to be done.

Knowledge and competence development: the competence base of employees need to be developed continuously, and should not be limited to only hiring competent employees for a short-term result. Over time organizations should train, and educate the employees to have an extended range of skills.

Rewards: Going hand in hand with employee empowerment is responsibility and rewards for taking such responsibilities. While increasing competencies is beneficial in itself, monetary rewards is a justification for it. However, both the dimensions are related to independence of the employee regarding work and service, and are all aimed at achieving organizational effectiveness and employee satisfaction as a way of achieving the organization's objectives. For this study purpose the researcher restricted on three variables, therefore according to Lashley (1997) cited in (T. Redman and A. Wilkinson , 2001) identified different factors of employee empowerment. Three of these variables are:

\section{Communication (Sharing Information)}

Sharing information play a vital role in the successful running of an organization. This gives the working people a sense of belonging and mutual trust. Information is also required to assess the future trends and performance modules. This is normally occurs in real organizations, where meetings of members and feedback from junior level employees keep up the flow of information giving an insight to day to day functions. They can interact personally to make amendments (Pattanayak, 2009)

Lashley (1997) cited in (T. Redman and A. Wilkinson , 2001) notes: For employees to be empowered, information is a central component. The logic here is that employees will be more understanding of the reasons for business decision and, as a result, more committed to the organization's decision. The aim is to have employees identifying more with the employer: 'them' becomes the competition and 'us' the company.

Basic to employee empowerment are programs to share information about business performance, plans, goals, and strategies. It is difficult to expect employees to make meaningful contributions to the success of the organization unless they have access to basic operating information. While organizations appear to be increasing efforts in this area, there is still a tremendous opportunity for greater sharing of business information with employees, particularly information about business operating results, competitors' performance, business plans and goals, and new technologies. Many public corporations, for example, provide only the financial information that the law requires be distributed to shareholders in annual reports. By not sharing basic information, a significant number of companies still do not treat employees as important stakeholders in and contributors to the firm's performance (Gary A. Yukl and Wendy S.Becker, 2006).

\section{Self-managing team}

Another type of program for increasing empowerment is the use of self-managed teams. Implementation of teams requires more structural change in the organization than the parallel structures. Unlike traditional work units where a formal manager usually makes all the key decisions, members of self managed teams meet to determine how to do the work and who will do each task (Gary A. Yukl and Wendy S.Becker, 2006). According to (K.K. Ahuja and B. Shukla , 2005), the important of group dynamics to manager lie in the fact that many people tend to act differently as individuals than as members of a group. To quote Likert, "An organization will function

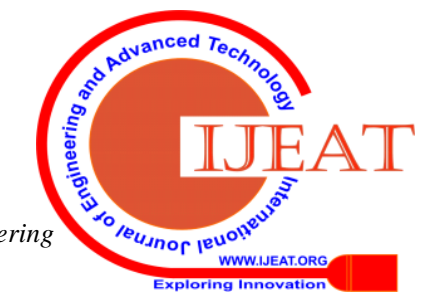


best when its personnel function not as individuals but as members of highly effective work groups with high performance goals". A manager is simultaneously the leader of his own group and a participating member of the group.

The advantage is that we have more freedom, no supervisor standing over our shoulder.

There is the satisfaction in handling problems, on our own. Ideally self-management should involve divisions between managers and workers being eroded and decisions, rule and executive authority no longer being set by the few for the many (semler, 1992 cited in (T. Redman and A. Wilkinson, 2001). Each team is usually given authority and responsibility for operating decisions such as setting performance goals and quality standards, assigning work, determining work schedules, determining work procedures, making purchases of necessary supplies and materials, dealing with customers and suppliers, evaluating team member performance, and handling performance problems of individual members. Self-managed work teams offer a number of potential advantages for an organization. Greater autonomy and variety can result in more satisfied employees, with lower turnover and absenteeism. Having team members cross-trained to do different jobs increases the flexibility of the team in dealing with personnel shortages resulting from illness or turnover. Increased knowledge of work processes helps team members solve problems and suggest improvements. Employees who can make decisions and initiate changes are more likely to take responsibility for their work and may be more motivated to produce a high-quality product or service. Finally, the changeover to self-managed groups typically reduces the number of managers and staff specialists in an organization, which lowers costs (GraryA. Yukl and Wendy S.Becker, 2006).

\section{Autonomy}

Autonomy may be defined as the degree to which one may make significant decisions without the consent of others. At various levels of analysis we may look at the autonomy of individuals within an organization or the autonomy of organizations or subunits thereof (Significant conditions in Employees Empowerment, 2004). Employees gain regarding to empowerment are autonomy and fulfillment through their contribution to the organization and the continuous development of skills and knowledge (Carroll, 1994).

At its most basic level this may mean removing inspectors from the production line as workers take on wider responsibility, or it may involve the more significant restructuring of work unit in to cells or teams, or the creation of semi autonomous work groups now commonly referred to team working or self-managing teams such team can have autonomy concerning task allocation and scheduling, monitoring of attendance, health and safety issue, the flow and pace of production and can also be responsible for setting important target (Wall and Martin,
1987 cited in (T. Redman and A. Wilkinson , 2001) .

\section{Empowerment in Practice}

According to Doughty A., journal (volume 9(1)), he normally associated it with Total Quality Management (TQM) or Quality of Working Life (QWL) innovators, employee empowerment has been an important part of the creative manager's tool- kit for about two decades. In his view, employee empowerment involves simple but important changes in managerial attitudes.

"Ask and listen," he says. "Instead of providing your thoughts, ask the employee four business altering words: 'What would you do?' When you do ask this question, the employee has the opportunity to openly express ideas, dreams and passions. You may already have an answer, but if the answer comes from the employee you now have: delegated this opportunity to someone passionate about the issue, a champion within the business to lead the implementation and change, an employee who is making a difference to the business" (A.Doughty, journal, volume 9(1)). The result is "a win-win-win situation. You win by delegating, the business wins by improving processes and, most importantly, the employee feels like the primary winner because they have the opportunity to implement their own ideas to an issue and bring about resolution. The time of change champions and exemplary followers had arrived. Amid all of this enthusiasm, however, it is important to recognize two enduring themes: in this approach: (1) empowerment is not about power; empowerment is about productivity (Ibid). First, the sharing of responsibility for decision making within a less hierarchical structure than was traditionally to be found in organized work situations is largely a matter of perception. While it is true that employees are now frequently consulted, that their suggestions may be taken seriously, and that their contributions might be implemented in policy and practice, the choice of whether or not to follow employees' recommendations remains an exclusive management right. Consultation and participation are not the same as ownership and control. When, therefore, rhetoricians of reform speak of employees "owning" some part of the productive process or even their own jobs, the word is being used metaphorically. It implies responsibility or even stewardship, but it does not imply final authority (Ibid).Second, the criteria according to which newly empowered employees will have their recommendations adopted all come down to the ubiquitous "bottom line." Improvements in working conditions, for example, will be embraced if they can be shown to increase profits for a private sector company or increase efficiency in the public service. This 
does not mean, of course, that mutually beneficial innovations cannot or do not exist. It only suggests that the overriding purpose of empowering employees is to encourage them to become self-starters, self- managers and self-disciplinarians in the ultimate interest of management. If, in the process, workers become happier and healthier, that is well and good but it is not the principal purpose of the exercise (A.Doughty, journal, volume 9(1).

\section{Employee Performance}

Organizations are formed and operated to produce goods and service for the large society. Job performance/JP/ is the direct and indirect contribution of an individual towards the organizational goals and objectives. As noted, Job performance is arguably one of the more important dependent variables of interest to educators, businesses, the government, and society (Maria Rotundo, 2002). According to the Miner, (1988) performacne also defind as the extent to which an individual meets the expectations regarding how he or she should function, or behave, on the job (Employees Empowerment, 2004). Performance is the level of how the activities serve the purpose. In other words, performance is "the rate of realization of the purpose" or "outcome level of the activity". This level shows how much the purpose or the objective is achieved. Institutionally, performance is defined differently according to different approaches. Performance is the level of reaching the target both for the institution and the individual. Considering the definition, it is understood that performance depends on the personal traits, mental abilities and eagerness to be integrated with institutional purposes of each individual (Hasan Tutar, Mehmet Altinoz and Demet Cakiroglu, 2011). Employee performance is about employees achieving the results, goals or standards as per the expectations set by the organization. Employees are rated on how well they do their jobs compared to the performance standards set. Employees who feel excluded or isolated in some way are less likely to do well. If an employee feels undervalued, there will be no incentive for them to work hard. An employee who feels isolated will be unlikely to ask for more work or draw any more attention to themselves. They may become unwilling to use their own initiative to solve problems or fill their days productively. You may discover that they have been spending a large amount of time surfing the Internet, and possibly even looking for another job while they are at work. Managers can deal with disenfranchised employees by monitoring their work closely. Set incremental targets that take progressively more concentration to achieve. Talk to your employee and ask for their opinions on how they feel they can be more productive. It may be that they do have some ideas, yet have felt unable to approach you with them. Job uncertainty can have a detrimental affect on employee performance. A prolonged period of restructuring or the threat of redundancy can quickly demoralize a workforce. Again, setting short term targets for your employees can help with this situation. It will help to keep your workers motivated, and focused on their immediate responsibilities (payne, 2010).

\section{Ways to Measure Employee Performance}

Employee performance is about employees achieving the results, goals or standards as per the expectations set by the organization. Employees are rated on how well they do their jobs compared to the performance standards set. In short, it is the accomplishment of a given task measured against pre-set standards of accuracy, completeness, cost, and speed, the initiatives they take, their creativity in solving problems and the resourcefulness in the way they utilize their resources, time and energy (Rothman \& Coetzer, 2003 cited in Chin , 2011). The performance of an individual should be assessed after a regular interval so that the desired behavior could be maintained. This will also help the organization to satisfy the needs and the aspiration of the individual by providing him more facilities, improving working conditions and career advancement (K.K. Ahuja and B. Shukla , 2005).

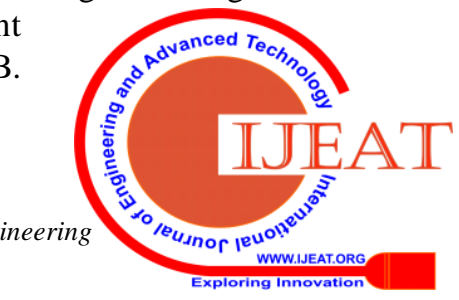


According to the Hakala, (2008) Performance measurement uses the following indicators of performance, as well as assessments of those indicators.

1. Quantity: The number of units produced, processed or sold is a good objective indicator of performance. Be careful of placing too much emphasis on quantity, lest quality suffer.

2. Quality: The quality of work performed can be measured by several means. The percentage of work output that must be redone or is rejected is one such indicator. In a sales environment, the percentage of inquiries converted to sales is an indicator of salesmanship quality.

3. Timeliness: How fast work is performed is another performance indicator that should be used with caution. In field service, the average customer's downtime is a good indicator of timeliness. In manufacturing, it might be the number of units produced per hour. 4. Cost-Effectiveness: The cost of work performed should be used as a measure of performance only if the employee has some degree of control over costs. For example, a customer-service representative's performance is indicated by the percentage of calls that he or she must escalate to more experienced and expensive reps.

5. Absenteeism/Tardiness: An employee is obviously not performing when he or she is not at work. Other employees' performance may be adversely impacted by absences, too. 6. Creativity: It can be difficult to quantify creativity as a performance indicator, but in many white-collar jobs, it is vitally important. Supervisors and employees should keep track of creative work examples and attempt to quantify them.

7. MBO (Management by Objectives): The employee's achievement of objective goals set in concert with his or her manager is assessed. The MBO process begins with action statements such as, "reduce rejected parts to 5 percent." Ongoing monitoring and review of objectives keeps the employee focused on achieving goals. At the annual review, progress toward objectives is assessed, and new goals are set. There are as many indicators of performance as there are companies and jobs. The various assessment methods can be used in combinations. It is important to choose indicators that align with your company's goals and assessment methods that effectively appraise those indicators.

\section{Benefits of improving job performance}

The success of any company can be determined by how well they are able to utilize and mobilize their resources to give them the best results. Unlike other resources, human resources have emotions and needs (Taljaard, 2003).)

Job performance can be affected by many things. An individual employee's performance can increase and decrease significantly over any given period. Looking at the factors that can have an impact on job performance can help managers to plan in advance for the slow times. Job performance can be affected by 2 main factors: internal and external events. Internal events will be things that happen while at work to the employee. External event are much harder for a manager to plan for as by their nature they happen away from the workplace. Internal factors can be real or perceived. An individual can either be directly affected by an event at work, or they can feel and respond to tension or a jubilant atmosphere. These can in turn affect an individual's performance. In a happy atmosphere at work, most people will thrive. Good team spirit encourages everyone to do their best, and being productive seems to require less effort overall. If you can foster a good atmosphere in your team, you can withstand many events that happen around you in the workplace (payne, 2010).

It is therefore imperative that management recognizes these emotions and needs when developing their human resource management systems. Effective development of these systems can provide a competitive human resource advantage. As access to capital and information becomes a less important means of advantage so does the human resource become an increasingly important means of differentiating oneself from one's competitors. This is the reason why a company's human resources are considered to be its most important asset (Taljaard, 2003).

In order to stay competitive and ensure that the company has a long-term future, it is important to improve these performances on an ongoing basis. These performances will only improve with the buy-in of the employees into higher levels of performance motivated by related rewards. The company will benefit because its labor productivity will increase, labor cost per unit will decrease and it will become more price competitive. This is especially the case where the manufacturing process is very labor intensive. The researcher therefore realizes the potential benefit in researching the effectiveness of non monetary reward systems in labor intensive companies. Improving job performance does not happen on its own, but gets driven by people's motivation. According to rewards and more specifically non-monetary rewards normally drive a person. It is therefore important to look at the payoffs of non-monetary rewards (Ibid).As different scholars and researchers stated at the above the organization will benefit because its labor productivity will increase, employees achieving the results, goals or standards as per the expectations set by the organization. Besides, improving job performance does not happen on its own, but gets driven by people's motivation.

\section{Countries experience about Employees' empowerment and its impact}

Indian organizations largely depend on management regarding employee empowerment practices. The adoption of effective employee empowerment practices in the institutions has remained challenging. There could be reasons for the existing situation but one main reason may be due to the emerging form of organizations. However, we can take employee empowerment practices experiences of other countries that are believed to be effective as compared to our current employee empowerment practices. In this regard, the researcher cited as a benchmark for

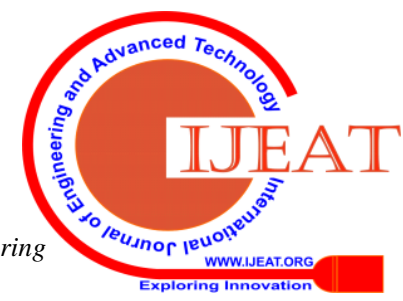


China and other who have adopted appropriate employee empowerment practices to record better performance from their employees. In this regard one of the experiences is that China's case study.

According the case study Employee Empowerment in China F.Littrell, (1993) stated the conclusion like, the results of the employee surveys in the samples show that more than half the respondents indicated that they were empowered in their ability to do their work as they deem fit. From results and those obtained, it seems obvious that the western concept of empowerment has application in job performance improvement in a conducive environment in China. As the feeling of empowerment is an attitude, opinion, or belief on the part of the employee, there will be cross-cultural differences relating to what empowerment actually means to the employee.

Moreover, according to paper the presented by Silvia C. Peters and Elham Mazdarani, (2008) in the case study of Länsförsäkringar Bank $\mathrm{AB}$ (LFB), uses employee empowerment as a tool to enable their employees to deliver the right kind of service quality the bank stands for. From the analysis the authors' found out that empowerment motivates the employees to greater service, and creates a greater sense of accomplishment or satisfaction in their jobs; by reducing dependency, irresponsibility and encouraging team work which overall leads to achieving organizational goals and objectives.

The authors' have also observed a relationship between employee empowerment, service quality and customer satisfaction. The organizational structure and the HRM practices empower the employees, who subsequently, influence the service quality perception by customers positively, and bring about customer satisfaction. In the authors' opinion, the empowerment of employees enables the employees to own the job, exert freedom while controlling the service process, and individually respond to customer needs in an excellent fashion. In addition, it enables employees to influence customers' perception of service quality positively, due to their control over the service delivery process, which leads to their customers' satisfaction. The authors' have arrived at a conclusion that employee empowerment impacts positively on service quality and customer satisfaction. LFB extensively practices employee empowerment through the actions and practices of human resource management and top management. The nature of their organizational structure influence the character of the services delivered through their employees (Silvia C. Peters and Elham Mazdarani, 2008).

\section{RESEARCH GAP}

Effective employee empowerment is important to any organizations success. Much research has been conducted in to identifying effective employee empowerment for enhancing employee performance in various sectors of countries including manufacturing, education sector, banks as well as non profit sectors. However the researcher found that there is lack of relatively little studies conducted on investigating the effect of employee empowerment towards employee job performance in the IT/ITES sector organizations mainly in India. Therefore, the study of the employee empowerment effect on the employee performance was conducted organizations.

\section{Conceptual frame work of the study}

The study is based on a conceptual construct indicating a relationship that exists between the different variables of employee empowerment such as: autonomy, information sharing and self directed work team exercised by the organizations by their employee and its consequence on employee performance in the study area. The independent variables of the study are employee empowerment (autonomy, information sharing and self directed work team). Hence, the dependent variable in this study will be employee performance. According to Nuhu.k, 2010 cited in adair, (2005), Performance was perceived as the ability of employees to meet organizational tasks, requirements and objectives through strategic investment in to organizing, executing and accomplishing roles and duties in the minimum time possible. Consequently, performance was operationally perceived as: Executing defined duties, meeting dead lines, team input, and achieving departmental goals. The above should lead to efficiency, specialization, effective feedback and good organizational relations.

Table- I: The improvement of employee performance

\begin{tabular}{|c|c|c|c|c|c|c|c|c|}
\hline \multirow[t]{2}{*}{ No } & \multirow[t]{2}{*}{ Item } & \multirow[t]{2}{*}{ Measurements } & \multicolumn{2}{|c|}{ Managements } & \multicolumn{2}{|c|}{ Officers } & \multicolumn{2}{|c|}{ Total } \\
\hline & & & No & $\%$ & No & $\%$ & No & $\%$ \\
\hline \multirow[t]{6}{*}{1} & \multirow{5}{*}{$\begin{array}{l}\text { You have greater enthusiasm } \\
\text { about work. }\end{array}$} & Stro. Disagree & - & - & 2 & .6 & 2 & 0.6 \\
\hline & & Disagree & - & - & 8 & 2.4 & 8 & 2.2 \\
\hline & & Neutral & - & - & 9 & 2.7 & 9 & 2.5 \\
\hline & & Agree & 12 & 42.9 & 133 & 40.3 & 145 & 40.5 \\
\hline & & Stro. Agree & 16 & 57.1 & 178 & 53.9 & 194 & 54.1 \\
\hline & Total & & 28 & 100 & 330 & 100 & 358 & 100 \\
\hline \multirow[t]{6}{*}{2} & \multirow{5}{*}{$\begin{array}{l}\text { There is any increased morale and } \\
\text { creativity of employee. }\end{array}$} & Stro. Disagree & - & - & 4 & 1.2 & 4 & 1.1 \\
\hline & & Disagree & - & - & 7 & 2.1 & 7 & 2 \\
\hline & & Neutral & - & - & 8 & 2.4 & 8 & 2.2 \\
\hline & & Agree & 10 & 35.7 & 128 & 38.8 & 138 & 38.5 \\
\hline & & Stro. Agree & 18 & 64.3 & 183 & 55.5 & 201 & 56.1 \\
\hline & Total & & 28 & 100 & 330 & 100 & 358 & 100 \\
\hline 3 & There is an improved quality of & Stro. Disagree & - & - & 1 & .3 & 1 & 0.3 \\
\hline
\end{tabular}


International Journal of Engineering and Advanced Technology (IJEAT) ISSN: 2249 - 8958, Volume-8, Issue-6S August 2019

\begin{tabular}{|c|c|c|c|c|c|c|c|c|}
\hline & \multirow[t]{4}{*}{ services provided to customers. } & Disagree & 3 & 10.7 & 41 & 12.4 & 44 & 12.3 \\
\hline & & Neutral & 9 & 32.1 & 45 & 13.6 & 54 & 15.1 \\
\hline & & Agree & 8 & 28.6 & 127 & 38.5 & 135 & 37.7 \\
\hline & & Stro. Agree & 8 & 28.6 & 116 & 35.2 & 124 & 34.6 \\
\hline & Total & & 28 & 100 & 330 & 100 & 358 & 100 \\
\hline \multirow[t]{6}{*}{4} & \multirow{5}{*}{$\begin{array}{l}\text { There is an improved goal } \\
\text { accomplishment through } \\
\text { teamwork. }\end{array}$} & Stro. Disagree & - & - & 3 & .9 & 3 & 0.8 \\
\hline & & Disagree & - & - & 12 & 3.6 & 12 & 3.4 \\
\hline & & Neutral & 3 & 10.7 & 22 & 6.7 & 25 & 7 \\
\hline & & Agree & 7 & 25.0 & 140 & 42.4 & 147 & 41.1 \\
\hline & & Stro. Agree & 18 & 64.3 & 153 & 46.4 & 124 & 34.6 \\
\hline & Total & & 28 & 100 & 330 & 100 & 358 & 100 \\
\hline \multirow[t]{6}{*}{5} & \multirow{5}{*}{$\begin{array}{l}\text { There is an increased speed to } \\
\text { accomplish job. }\end{array}$} & Stro. Disagree & - & - & 2 & .6 & 2 & 0.6 \\
\hline & & Disagree & - & - & 9 & 2.7 & 9 & 2.5 \\
\hline & & Neutral & - & - & 2 & .6 & 2 & 0.6 \\
\hline & & Agree & 10 & 35.7 & 138 & 41.8 & 148 & 41.3 \\
\hline & & Stro. Agree & 18 & 64.3 & 179 & 54.2 & 197 & 55 \\
\hline & Total & & 28 & 100 & 330 & 100 & 358 & 100 \\
\hline \multirow[t]{6}{*}{6} & \multirow[t]{5}{*}{ There is high responsiveness. } & Stro. Disagree & - & - & 1 & .3 & 1 & 0.3 \\
\hline & & Disagree & - & - & 10 & 3.0 & 10 & 2.8 \\
\hline & & Neutral & - & - & 5 & 1.5 & 5 & 1.4 \\
\hline & & Agree & 8 & 28.6 & 139 & 42.1 & 147 & 41.1 \\
\hline & & Stro. Agree & 20 & 71.4 & 175 & 53.0 & 195 & 54.5 \\
\hline & Total & & 28 & 100 & 330 & 100 & 358 & 100 \\
\hline
\end{tabular}

TABLE II: The productivity of employees

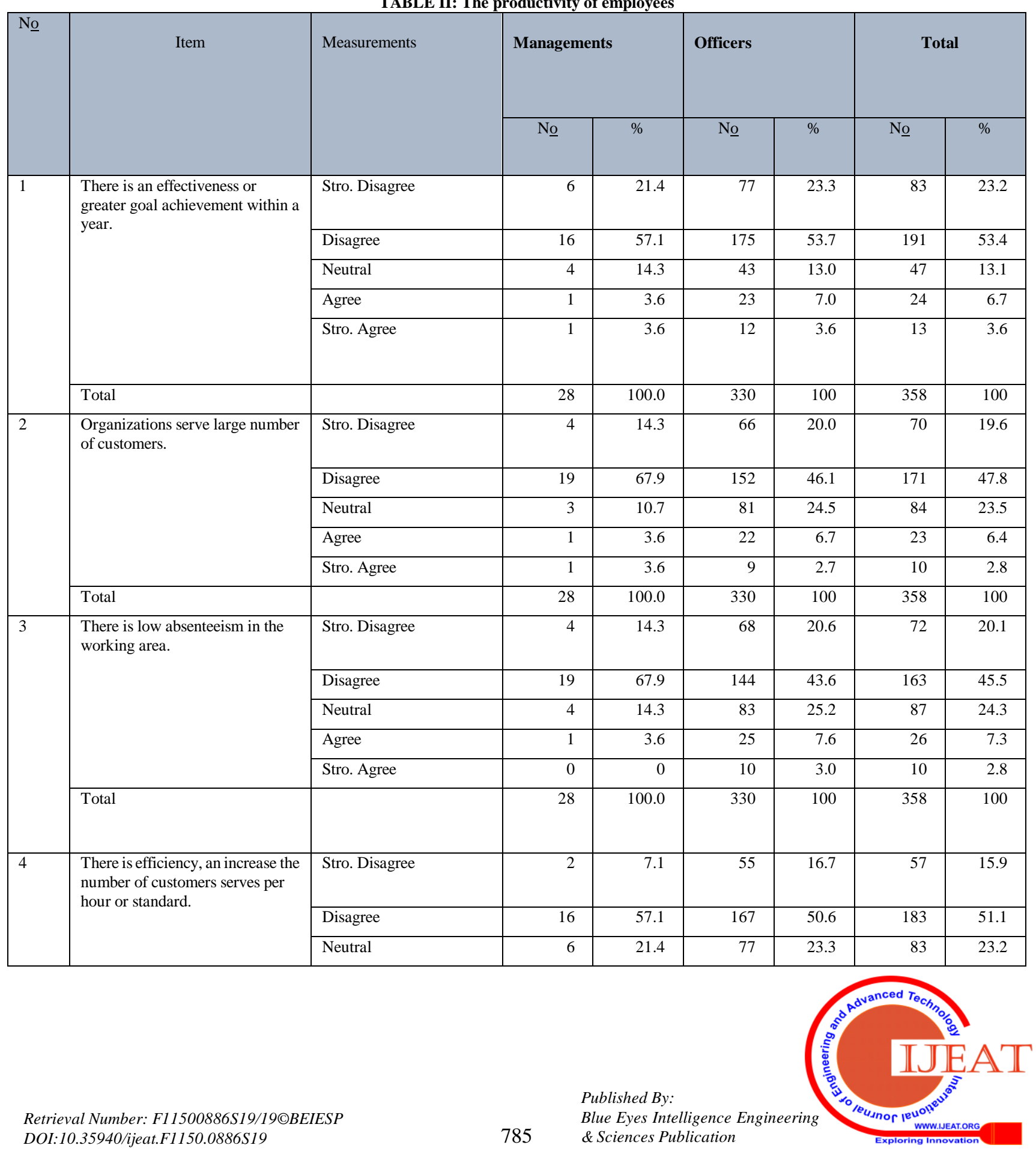


Employee Empowerment and Job Performance: The case of a Few Selected BPOs/KPOs in the City of Pune

\begin{tabular}{|c|c|c|c|c|c|c|c|}
\hline & Agree & 2 & 7.1 & 28 & 8.5 & 30 & 8.4 \\
\hline & Stro. Agree & 2 & 7.1 & 3 & .9 & 5 & 1.4 \\
\hline Total & & 28 & 100.0 & 330 & 100 & 358 & 100 \\
\hline
\end{tabular}

TABLE III: Challenges regarding to employee empowerment

\begin{tabular}{|c|c|c|c|c|c|c|c|c|}
\hline \multirow[b]{2}{*}{ No } & \multirow[b]{2}{*}{ Item } & \multirow[b]{2}{*}{ Measurements } & \multicolumn{2}{|c|}{ Managements } & \multicolumn{2}{|c|}{ Officers } & \multicolumn{2}{|c|}{ Total } \\
\hline & & & N. & $\%$ & N. & $\%$ & N. & $\%$ \\
\hline \multirow[t]{6}{*}{1} & \multirow{5}{*}{$\begin{array}{l}\text { Lack of long and short term } \\
\text { training }\end{array}$} & Stro. Disagree & 1 & 3.6 & 12 & 3.6 & 13 & 3.6 \\
\hline & & Disagree & 3 & 10.7 & 29 & 8.8 & 32 & 9 \\
\hline & & Neutral & 1 & 3.6 & 49 & 14.8 & 50 & 14.2 \\
\hline & & Agree & 11 & 39.3 & 84 & 25.5 & 95 & 27 \\
\hline & & Stro. Agree & 12 & 42.9 & 156 & 47.3 & 168 & 47 \\
\hline & Total & & 28 & 100 & 330 & 100 & 358 & 100 \\
\hline \multirow[t]{6}{*}{2} & \multirow{5}{*}{$\begin{array}{l}\text { Lack of clear role and } \\
\text { responsibility }\end{array}$} & Stro. Disagree & 1 & 3.6 & 8 & 2.4 & 9 & 2.5 \\
\hline & & Disagree & 12 & 42.9 & 39 & 11.8 & 51 & 14.2 \\
\hline & & Neutral & 2 & 7.1 & 48 & 14.5 & 50 & 13.9 \\
\hline & & Agree & 8 & 28.6 & 137 & 41.5 & 145 & 40.5 \\
\hline & & Stro. Agree & 5 & 17.9 & 98 & 29.7 & 103 & 28.8 \\
\hline & Total & & 28 & 100 & 330 & 100 & 258 & 100 \\
\hline \multirow[t]{6}{*}{3} & \multirow[t]{5}{*}{ Lower level of trust } & Stro. Disagree & 1 & 3.6 & 7 & 2.1 & 8 & 2.2 \\
\hline & & Disagree & 13 & 46.4 & 30 & 9.1 & 43 & 12 \\
\hline & & Neutral & 3 & 10.7 & 63 & 19.1 & 66 & 18.4 \\
\hline & & Agree & 9 & 32.1 & 135 & 40.9 & 144 & 40.2 \\
\hline & & Stro. Agree & 2 & 7.1 & 95 & 28.8 & 97 & 27 \\
\hline & Total & & 28 & 100 & 330 & 100 & 358 & 100 \\
\hline \multirow[t]{6}{*}{4} & \multirow[t]{5}{*}{ Minimum rank of promotion } & Stro. Disagree & 2 & 7.1 & 10 & 3.0 & 12 & 3.35 \\
\hline & & Disagree & 11 & 39.3 & 24 & 7.3 & 35 & 9.77 \\
\hline & & Neutral & - & - & 60 & 18.2 & 60 & 16.8 \\
\hline & & Agree & 10 & 35.7 & 135 & 40.9 & 145 & 40.5 \\
\hline & & Stro. Agree & 5 & 17.9 & 101 & 30.6 & 106 & 29.6 \\
\hline & Total & & 28 & 100 & 330 & 100 & 358 & 100 \\
\hline \multirow[t]{6}{*}{5} & \multirow{5}{*}{$\begin{array}{l}\text { Lack of clear performance } \\
\text { evaluation }\end{array}$} & Stro. Disagree & 1 & 3.6 & 16 & 4.8 & 17 & 4.7 \\
\hline & & Disagree & 8 & 28.6 & 29 & 8.8 & 37 & 10.3 \\
\hline & & Neutral & 1 & 3.6 & 37 & 11.2 & 38 & 10.6 \\
\hline & & Agree & 13 & 46.4 & 137 & 41.5 & 150 & 41.9 \\
\hline & & Stro. Agree & 5 & 17.9 & 111 & 33.6 & 116 & 32.4 \\
\hline & Total & & 28 & 100 & 330 & 100 & 358 & 100 \\
\hline \multirow[t]{5}{*}{6} & \multirow{5}{*}{$\begin{array}{l}\text { Lower attention to work team } \\
\text { formation }\end{array}$} & Stro. Disagree & 3 & 10.7 & 10 & 3.0 & 13 & 3.6 \\
\hline & & Disagree & 16 & 57.1 & 172 & 52.1 & 188 & 52.5 \\
\hline & & Neutral & 3 & 10.7 & 48 & 14.5 & 51 & 14.2 \\
\hline & & Agree & 6 & 21.4 & 47 & 14.2 & 53 & 14.8 \\
\hline & & Stro. Agree & - & - & 53 & 16.1 & 53 & 14.8 \\
\hline
\end{tabular}

\begin{tabular}{|c|c|c|c|c|c|c|c|c|}
\hline \multirow[b]{2}{*}{ № } & \multirow[b]{2}{*}{ Item } & \multirow[b]{2}{*}{ Measurements } & \multicolumn{2}{|c|}{ Managements } & \multicolumn{2}{|c|}{ Officers } & \multicolumn{2}{|c|}{ Total } \\
\hline & & & N. & $\%$ & N. & $\%$ & N. & $\%$ \\
\hline \multirow[t]{6}{*}{7} & \multirow{5}{*}{$\begin{array}{l}\text { Lack of autonomy for } \\
\text { workers in their jobs. }\end{array}$} & Stro. Disagree & 1 & 3.6 & 14 & 4.2 & 15 & 4.1 \\
\hline & & Disagree & 13 & 46.4 & 30 & 9.1 & 43 & 12 \\
\hline & & Neutral & - & - & 42 & 12.7 & 42 & 11.7 \\
\hline & & Agree & 12 & 42.9 & 105 & 31.8 & 117 & 32.7 \\
\hline & & Stro. Agree & 2 & 7.1 & 139 & 42.1 & 141 & 39.4 \\
\hline & Total & & 28 & 100 & 330 & 100 & 358 & 100 \\
\hline \multirow[t]{6}{*}{8} & \multirow{6}{*}{$\begin{array}{l}\text { Low level of experience } \\
\text { sharing between employees }\end{array}$} & Stro. Disagree & 2 & 7.1 & 6 & 1.8 & 8 & 2.2 \\
\hline & & Disagree & 11 & 39.3 & 44 & 13.3 & 55 & 15.4 \\
\hline & & Neutral & - & - & 36 & 10.9 & 36 & 10 \\
\hline & & Agree & 11 & 39.3 & 136 & 41.2 & 147 & 41.1 \\
\hline & & Stro. Agree & 4 & 14.3 & 108 & 32.7 & 112 & 31.3 \\
\hline & & & 28 & 100 & 330 & 100 & 358 & 100 \\
\hline \multirow[t]{2}{*}{9} & \multirow{2}{*}{$\begin{array}{l}\text { Lack of monitoring for } \\
\text { workers }\end{array}$} & Stro. Disagree & 3 & 10.7 & 11 & 3.3 & 14 & 3.9 \\
\hline & & Disagree & 11 & 39.3 & 207 & 62.7 & 218 & 60.9 \\
\hline
\end{tabular}


International Journal of Engineering and Advanced Technology (IJEAT)

ISSN: 2249 - 8958, Volume-8, Issue-6S August 2019

\begin{tabular}{|c|c|c|c|c|c|c|c|c|}
\hline & & Neutral & 1 & 3.6 & 36 & 10.9 & 37 & 10.3 \\
\hline & & Agree & 8 & 28.6 & 19 & 5.8 & 27 & 7.5 \\
\hline & & Stro. Agree & 5 & 17.9 & 57 & 17.3 & 62 & 17.3 \\
\hline & Total & & 28 & 100 & 330 & 100 & 358 & 100 \\
\hline \multirow[t]{6}{*}{10} & \multirow[t]{5}{*}{ Lack of clear job description } & Stro. Disagree & 1 & 3.6 & 9 & 2.7 & 10 & 2.8 \\
\hline & & Disagree & 17 & 60.7 & 41 & 12.4 & 58 & 16.2 \\
\hline & & Neutral & - & - & 48 & 14.5 & 48 & 13.4 \\
\hline & & Agree & 6 & 21.4 & 131 & 39.7 & 137 & 38.3 \\
\hline & & Stro. Agree & 4 & 14.3 & 101 & 30.6 & 105 & 29.3 \\
\hline & Total & & 28 & 100 & 300 & 100 & 358 & 100 \\
\hline
\end{tabular}

The above table summarizes about challenges regarding to employee empowerment practices in the organization. The total response of both employees groups agreed or not about lack of long and short term training, around $74 \%$ of respondents replied that they agreed. Regarding to management around $12(42.9 \%)$ of respondents of management replied that they strongly agreed and $11(39.3 \%)$ of respondents replied, agreed regarding to lack of long and short term training in the organization. While, around $3(10.7 \%)$ of respondents replied that disagreed about lack of long and short term training. around 156(47.3\%) of the respondents replied that strongly agreed and $84(25.3 \%)$ of the respondents replied that agreed about with the statement that lack of long and short term training. While, around $49(14.8 \%)$ of the respondents replied neutral and $29(8.8 \%)$ of the respondents disagreed about the issue. From this we can say that long and short term training is not that much enough in the organization.

Regarding to the total response of both groups, around $68 \%$ of respondents of management replied that agreed out of 358 about lack of clear role and responsibility. When the researcher asked management to what extent respondents agree or disagree about their lack of clear role and responsibility in the organization, around $12(42.9 \%)$ of respondents of management replied that they disagreed and $1(3.6 \%)$ of management respondents claimed to strongly disagreed. But, around $8(28.6 \%)$ of them replied that agreed and $5(17.9 \%)$ of them claimed to strongly agreed. According to the employees $137(41.5 \%)$ of the respondents replied that they agreed and $98(29.7 \%)$ of the respondents replied that strongly agreed about the organization had lack of clear role and responsibility, And around 48 (14.5\%) of the respondents replied neutral. But around 39(11.8\%) of the respondents replied that disagreed about the organization had lack of clear role and responsibility. It confirming what both respondents said that they were the majority was disagreed about availability clear role and responsibility to their employees'.

From the total of 358 respondents around $67 \%$ of them replied that they agreed about lower level of trust of the employees. Regarding management about lower level of trust and responsibility, about $13(46.4 \%)$ of them claimed to disagree and about $1(3.6 \%)$ of respondents replied strongly disagreed. But about $9(32.1 \%)$ of respondents replied that they agreed and about $2(7.1 \%)$ of respondents replied that they strongly agreed regarding to lower level of trust and responsibility. However, from some employees of the respondents $135(40.9 \%$ ) and $95(28.8 \%)$ of the respondents replied that they agreed and strongly agreed respectively about respondents had lower level of trust and responsibility.
Hence, $63(19.1 \%)$ of the respondents were replied that neutral. And $30(9.1 \%)$ of the respondents were replied that disagreed and $7(2.1 \%)$ of the respondents were replied that disagreed. This implies that most of the total respondents believe that this challenges are theirs. When we see the total response around $69 \%$ of 358 respondents replied that they agreed about minimum rank of promotion in the organization. When the researcher asked the management the extent to which they agree or not that, there is minimum rank of promotion for employees, around 11(39.3\%) and $2(7.1 \%)$ of the managements respondents disagreed and strongly disagreed respectively about the issue and on the other side, around $10(35.7 \%)$ and $5(17.9 \%)$ of the respondents replied to have agreed and strongly agreed about it. But, employees 135(40.9\%) and 101(30.6\%) of respondents were replied that agreed and strongly agreed about the organization gave minimum rank of promotion to employee, around $24(7.3 \%)$ and $10(3.0 \%)$ of respondents were replied that disagreed and strongly disagreed about the organization gave minimum rank of promotion to employee. And $60(18.2 \%)$ of respondents were replied that neutral. This indicates that the level of rank promotion in the organization was not that much enough to encourage employees'.

Regarding to total response of $73 \%$ of 358 were replied that agreed about lack of clear performance evaluation. About management to what extent agree or disagree there is lack of clear performance evaluation in the organization, around $13(46.4 \%)$ of respondents of management were replied that agreed and 5(17.9\%) of respondents were replied strongly agreed. Hence, around $8(28.6 \%)$ of respondents were replied that strongly disagreed and 1(3.6\%) of respondents were replied strongly disagreed. About large numbers of employees were 137(41.5\%) and 111(33.6\%) of the respondents replied that agreed and strongly agreed respectively with the statement that lack of clear performance evaluation in the organization. And around 35(11.2\%) of the respondents replied that neutral. Hence, around 29(8.8\%) and $16(4.8 \%)$ of the respondents replied that disagreed and strongly disagreed respectively.

It confirming what respondents said that employees commission were not had clear performance evaluation. Therefore performance evaluation criteria not clear means any promotion and recognition of employees contribution is not happening or not clear to employees' and it may create negative effect on job performance of the employees.

\section{CONCLUSION}

The success of the organization is now in the 
hands of employees to deliver it. So in recent years empowerment has become the latest thing in different organization. Empowerment has become important for services, to enhance service quality by improving job to performance. Job performance/JP/ is the direct and indirect contribution of an individual towards the organizational goals and objectives. The main objectives of this study were to explore the impact of employee empowerment on their job performance. Employee empowerment has three variables; these are Autonomy, Information sharing and self managing team affect job performance of employee.

The research has been designed as a descriptive study. Both primary and secondary data were used in the research. A survey questionnaire with five point Likert scale was a main tool for gathering primary data about employee empowerment effect on job performance. In addition to this, the researcher conducted interview with human resource experts of the organization.

Hence, it is quite clear that there is an improvement in the organization. But, the employees ability to perform jobs and goal achievement are generally not enough. There is interference of supervisory, and most of the time employees are not have freedom to make decisions by themselves. This shows that, autonomy is not properly practiced in the organization. In addition, self-management team and information sharing among the three employee empowerment variables used in the study are not that much practiced similarly as autonomy.

From responses of respondents the researcher can concluded that respondents are believed and recognized most of the time management are not create understanding about the reasons for decision of the organization to employees. But they noted that, the organization provided and gave a chance to employees to participate in various form of information sharing mechanisms about organization's performance, plans, goals, and strategies. The importance of Information sharing is creating senesce of belongingness of organizational work and also create conducive work environment.

On average the ability of employees officers to perform the planed job and goal achievement are generally satisfactory but not enough. It is quite clear that there is an improvement but such employee empowerment is not well practiced to enhance efforts of employees to attain the objective of the organization. Based on the reasons of majority of them are not available at work environment and the numbers of customers serves per hour is low. Workers effort affects to attain the objective of the organization that leads employees to less job performance. Furthermore, from responses of respondents the researcher concluded that there are challenges, some of them are lack long and short term training, lower level of trust and responsibility, lower level of rank promotion, lack of clear performance evaluation, lack of freedom, low level of experience sharing and lack of clear job description.

Finally, concluding the whole research conducted it is found that Employee Empowerment is not that much effective in the organization. Because, which is not planned, systematic and implemented by employees organization to increase performance and this further result as organization productivity not that much show growth and good performance.

\section{RECOMMENDATIONS}

The recommendation is directed towards the top management and human resource of the organization and the concerning bodies for the development of employees. It starts with the appreciation of the current movement on assuring employees' empowerment and suggesting that what is being done so far is very encouraging but not good enough.

Therefore, in order to improve and maintain, the following measures are proposed. These are:

- The organization should create an empowerment culture (autonomy, information sharing and self managing team) by encouraging employees' to exercise initiative and imagination in solving problems, improve processes and meet customer needs, The management create this culture by using awareness creation method like training about the meaning of empowerment and communicate their level of empower to every member of the organization,

- Organization should establish an empowerment vision; enhance both the individuals and the organizations ability to act in order to ensure improved organizational goal achievement and customer service. And should set goals and objectives that help them to undertake their own efforts to extend and strengthen empowerment. It has to be evaluate and continually improve the process of empowerment by measuring improvement and the perceptions of the organization's members,

The organization should give Autonomy to their employees. By enhancing the degree to which employees make significant decisions without the consent of others and at its most basic level this may mean removing interference supervisors from the production line as well as workers take on wider responsibility.

Organizations going through change must stay in constant communication or information sharing with all its employees'. If employees' feel included and informed about organizational change, main decision and how it is impacting them on an ongoing basis, there is a greater likelihood that they will see themselves as part of the whole team and pull together for the good of the organization. Therefore, the management should facilitate different formal and informal forums to employees' in order to create trust and communication between them.

Top managements should discuss briefly the objectives of the organization with all employees'. Furthermore, the management ought to explain how each jobs related with the objectives to maintain employee's perception. And create understanding about their contribution

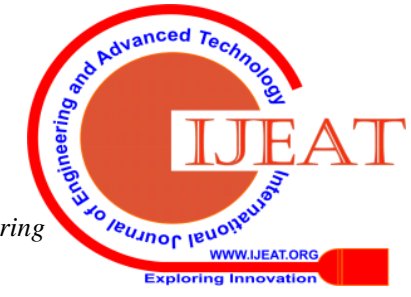


vital to attain organizational goal.

Management of the organization should create conducive work area to improve the coordination of employees' in the organization. Therefore, top management should work hard to bridge the gap between management and employees' like, approaching lower level employees' to communicate and gather feedbacks on the existing situation to avoid insubordination.

Another type of program for increasing empowerment is the use of self-managed teams. The management should give more freedom, no supervisor standing over their shoulder and given authority and responsibility for operating decisions such as setting performance goals and quality standards of their work by them selves.

The findings of this study suggest that the organization should develop strategies to meet the rank promotion needs of all employees' to foster their competence and further enhance organizational productivity. The management of the organization should communicate with employees' to give clear information about the rules, procedures and practices of rank promotion in the organization.

Organization should be provided to short term and long term training for all employees' to improve the ability of workers to perform the promised service to the consumers accurately and timely without error.

It is essential to redesign jobs to avoid and lack of clear job description and lack of trust and responsibility. Job description should be restructuring of the content and level of responsibility of a job to make it more clear and meaningful, and interesting to a work. Moreover, they should be clear performance evaluation. Supervision' of employees' in the organization ought to be conducted based on the job requirements.

\section{REFERENCES}

1. Amaanda, N. (2011). The impact of employee's motivation and Empowerment on delivering service quality to enhance customer satisfaction. Retrieved 05 12, 2013, from http://publications.theseus.fi/bitstream/handle/10024/27677/march\%20f inal\%20theaia\%201.pdf? sequence $=1$.

2. Beardwell, I., Holden, L. and Caydon, T.. (2004). HUMAN RESOURCE MANAGEMENT, Acontemprary approach, fourth edition. England.

3. Becker, G. (2006). Effective Empowerment in Organizations. Retrieved 9 24, 2018, from http://www.ascld.org/files/Becker\%20ASCLD.pdf.

4. Boddy, D. (2011). Management: An Introduction

5. Calderon, j. (1967). Method of Research and Thesis Writing. printing co.Inc.

6. Carroll, A. (1994). Empowerment. Retrieved 09 01, 2018, from http://www.interactiondesign.com/downloads/empwrart.pdf

7. Cherrington, D. (1994). Organization Behavior: the management of individual and organizational performance.

8. Dimitriades, Z. and Maroudas, T. (2007). Internal Service Climate and Psychological Empowemrent among public Employee: Emerald Group Publishig .

9. Doughty, A. (journal, volume 9(1)). Employee Empowerment. Retrieved $5 \quad 12, \quad 2018$ from http://www.centreforum.org/assets/pubs/workplace-democracy.pdf.

10. Hakala, D. (2008). performance measure. Retrieved 09 2018, from http://www.hrworld.com/features/16-ways-measure-performance-02190 $8 /$.

11. Indradevi, R. (2012). Empowerment on Job Performance And Job Satisfaction.. $\quad$ Retrieved $8 \quad 31$, 2018, from http://www.jgbm.org/page/13\%20Gao-Liang\%20Wang.pdf .

12. Indradevi, R.. (2012). Re: Empowerment on Job Performance And Job Satisfaction. Retrieved $10 \quad 26, \quad 2018$, from

http://zenithresearch.org.in/im

13. Ivancevich, M. (1990). Organizational Behavior and Management, second international edition, IRWIN, Boston.

14. Jordanian. (2004). Significant conditions in Employees Empowerment. Retrieved sep 4, $2018 \quad$ from http://anzmac2010.org/proceedings/pdf/anzmac10Final00157.pdf .

15. Koontz, H.and Weihrich, H. (2005). Organizational Behavior.

16. KREJCIE, R. and MORGAN, D. (1970). DETERMINING SAMPLE SIZE FOR RESEARCH

17. Kothari, R. (2004). Research methodology Methods and Techniques (Second Edition). New Delhi: New Age International (P) Limited.

18. Littrell, F. (1993). Employee Empowerment in china, A case study. Retrieved 52018 , 12, from http://romielittrellpubs.homestead.com/files/empowerment_cn_rev1.htm

19. Mosley, C., pietri, H. and Mosley, C. (2008). supervisory managenent: The art of inpiring, Empoering, and developloping people .

20. Nuhu, k. ( 2010). Effect of leadership styles on employee performace in district council .

21. Pattanayak, B. (2009). Human Resource Management.

22. Payne, s. (2010). factor that affect job performance http://www.helium.com/items/1925389-factors-that-affect-job-performa nce

23. Rasid and Archer. (1982). Organizational Behevior: Employee satisfaction and jop Enrichment

24. Redman, T. and Wilkinson, A. (2001). Contemporary Human Management: Empowerment.

25. Rotundo, M. (2002). Defining and Measuring Individual Level Job Performance. Retrieved 1 8, 2018, from citeseerx.ist.psu.edu/viewdoc/download?doi=10.1.1.129...pdf .

26. Shukla, B. and Ahuja, K. (2005). Human Resource Management.

27. Significant conditions in Employees Empowerment. (2004). Retrieved from

http://unpan1.un.org/intradoc/groups/public/documents/arado/unpan020 796.pdf

28. Silvia C. Peters and Elham Mazdarani. (2008). The impact of employee empowerment on service quality and customer satisfaction in the organizations. Retrieved 5 12, 2018, from mdh.diva-portal.org/smash/get/diva2:121413/FULLTEXT01/.

29. State, T. A. (2011). Amhara Region . Retrieved 12 31, 2018, from http://www.ethiopia.gov.et/English/Information/Pages/StateAmhara.asp

30. Tutar, H., Altinoz, M. and Cakiroglu, D. (2011). The effects of employee empowerment on contextual performance of employees. Retrieved 0903 2018 , http://www.academicjournals.org/ajbm/pdf/pdf2011/4Aug/Tutar\%20et $\% 20$ al.pdf.

31. Taljaard, J. (2003). Improving job performance by using non-monetary reward. Retrieved $02 \quad 21, \quad 2018$, from dspace.nmmu.ac.za:8080/jspui/bitstream/10948/131/1/TaljaardJJ.pdf.

32. THERON, C.-J. (2010). EMPOWERMENT AND JOB SATISFACTION. Retrieved 08 06, 2012, from http://www.academicjournals.org/AJBM/PDF/pdf2011/4Aug/Tutar\%2 0et\%20al.pdf.

33. Yukl, G. and Becker, W. (2006). Effective Empowerment. Retrieved 09 24, 2018, from http://www.ascld.org/files/Becker\%20ASCLD.pdf.

34. Wilkinson, T. R. (2001). Contemporary Human Management: Empowerment

35. Wörlein, J. (2010). Employees Empowerment. Retrieved 11 25, 2018 from

http://openeasy.pbworks.com/f/Review+Paper+-+Empowerment+of+E mployees.pdf. 